4. Державна Фармакопея України / Державне підприємство «Український науковий фармакопейний центр якості лікарських засобів». - 2-е вид. - Доповнення 4. - Харків: Державне підприємство «Український науковий фармакопейний центр якості лікарських засобів», 2020. 105 с.

5. Do Q.D. Effect of extraction solvent on total phenol content, total flavonoid content, and antioxidant activity of Limnophila aromatica / Q.D. Do, A.E. Angkawijaya, P.L. Tran-Nguyen [et al] // Journal of Food and Drug Analysis. - 2014. - № 22. - P. 296-302.

6. Determination of total phenolic content, total flavonoid content, and antimutagenic activity of ethanol extract nanoparticles of rhaphidophora pinnata (L.f) schott leaves / Sumaiyah, Masfria and A. Dalimunthe // Rasayan Journal of Chemistry. - 2018. - № 2. - P. 505-510.

DOI https://doi.org/10.30525/978-9934-26-075-9-42

\title{
ПІДХОДИ ДО ВІДНОВЛЕННЯ ПОРУШЕНОЇ СМАКОВОЇ ТА НЮХОВОЇ ЧУТЛИВОСТІ ВНАСЛІДОК IНФІКУВАННЯ SARS-COV-2
}

\author{
Луцак I. B. \\ кандидат фармачевтичних наук, \\ викладач фармачевтичних дисциплін \\ Житомирський базовий фармачевтичний фаховий коледж \\ Косяченко Н. М. \\ кандидат фармацевтичних наук, \\ викладач фармачевтичних дисциплін \\ Житомирський базовий фармачевтичний фаховий коледж \\ Зубрицька Т. P. \\ викладач фармачевтичних дисциплін \\ Житомирський базовий фармацевтичний фаховий коледж \\ м. Житомир, Украӥна
}

Актуальність. 3 активним поширенням коронавірусної інфекції, погіршення смакового і нюхового сприйняття привернуло увагу як науковців так і пацієнтів в усьому світі. Очевидним постав зв'язок між вказаними порушеннями і COVID, оскільки втрату здатності відчувати 
запах і смак фіксували в людей, які були заражені коронавірусом, але не мали інших симптомів. Причому дисфункція запаху та смаку мала високу частоту поширеності в Свропі, Північній Америці та на Близькому Сході і дещо нижчою в Азійському регіоні [9]. Хоча зниження здатності ідентифікувати та розрізняти основні смаки, запахи не $\epsilon$ фатальними симптомами, однак вони значно впливають на численні аспекти здоров'я людини, суттєво погіршуючи якість життя [3]. Відчуття смаку та запаху відіграють життєво важливу роль у передачі інформації про нас самих та навколишнє середовище. Смаки та запахи можуть застерегти від небезпеки, вживання недоброякісних або отруйних речовин. Для людей похилого віку втрата смаку спричинює серйозні наслідки - призводить до погіршення апетиту, недостатнього харчування і втрати ваги.

Раніше в медицині даному порушенню не приділялася значна увага, 3 огляду на це практично не має достатньо даних результатів клінічних досліджень стосовно лікування вказаних порушень. Закономірним $\epsilon$ занепокоєння як пацієнтів, так і лікарів у можливості відновлення хіміосенсорних порушень. Таким чином, існує нагальна потреба у визначенні ефективних методів лікування.

Мета дослідження. Основною метою роботи було провести аналіз наукових джерел та систематизувати дані про наявні рекомендації щодо лікування порушень смаку і запаху, зокрема спричинених вірусами, такими як SARS-CoV-2.

Матеріали та методи. Наукові публікації бази даних PubMed, Google Scholar 3 ключовими пошуковими словами на тему лікування розладів смаку та запаху.

Результати. Огляд сучасних досліджень показує, що ми маємо сплеск поширення нюхових і смакових дисфункцій, які сталися під час епідемії інфекції COVID-19. Більшість досліджень (95,8\%) підтвердили симптоми аносмії у пацієнтів з інфекцією ГРВI-CoV-2. Крім аносмії, у пацієнтів 3 COVID-19 спостерігались також дані про агевзію та дисгевзію (парагевзію) [6]. Згідно даних дослідження [8] симптоми аносмії та дисгевзії були наявні у 74,9\% та $81,3 \%$ амбулаторних, а також госпіталізованих, легких та важких випадках пацієнтів із COVID-19 відповідно. Дані з Свропи, США та Ірану вказують, що нюхові та смакові симптоми з'являються до загальних симптомів COVID-19 у 64,5\% та 54,0\% пацієнтів відповідно [5].

Згідно спостережень вчених Королівського національного ЛОРкабінету та стоматологічної лікарні Істмена, пацієнти з COVID-19 втрачають нюх, оскільки вірус пошкоджує нервові закінчення нюхових 
рецепторів або нюхові клітини носа. Поки невідомо, наскільки довготривалим може бути розлад, припускається, що регенерація може тривати до 18 місяців. Втрата нюху та смаку зберігається приблизно у $10 \%$ постраждалих впродовж 6 місяців. Надходило чимало свідчень, що пацієнти відзначають часткове відновлення нюху та смаку, але замість цього описують спотворені запахи та смаки. Імовірність повернення запаху корелюється із тяжкістю втрати запаху.

Ряд досліджень, проведених за останнє десятиліття, свідчать про те, що повторний короткочасний вплив запахів може допомогти людям, які втратили нюх. Для вивчення розладів запаху після зараження вивчали різні методи лікування, при цьому нюхове тренування вважається перспективним варіантом лікування. Встановлено, що нюхове тренування покращує стан постінфекційної нюхової дисфункції, а використання запахів при більш високих концентраціях корисно для поліпшення [2]. Оцінка ефективності та безпеки нюхових тренувань для пацієнтів із COVID-19 та розладами запаху стали основною метою протоколу [10] i відзначили його високу безпеку та ефективність. Пацієнти з нюховою дисфункцією отримали користь від повторного впливу запахів, так званого нюхового тренування. В процесі дослідження спостерігали вплив не випадкових різних запахів, а структуроване нюхання певного запаху, двічі на день, протягом 4 місяців або довше. У проспективному дослідженні [2] спостерігали ефект посилення дії за рахунок використання більшої кількості запахів та продовження періоду навчання. В результаті встановлено ефективність самого тренування і доведено, що збільшення тривалості тренінгу та зміна запахів підвищують рівень успіху цієї терапії [4].

Таким чином, нюхове тренування $\epsilon$ безпечною процедурою $\mathrm{i}$ виявляється особливо корисною у пацієнтів, які починають ії протягом 12 місяців від початку розладу. Подібне твердження узгоджується 3 висновками конференції науковців Оксфордського університету на тему «Визначення методів лікування розладів смаку та запаху», яка об'єднала вчених, медичних працівників, пацієнтів та представників пацієнтів, які запропонували ряд заходів [1]. Запропоновані заходи спрямовані на підвищення обізнаності про руйнівні наслідки дисфункції смаку або запаху та сприяють отримати державну та фінансову підтримку, що $є$ запорукою для продовження ряду досліджень, направлених на регенерацію втрачених або пошкоджених нюхових та рецепторних клітин i додатково повинні бути підкріплені потужною програмою досліджень для виявлення всіх цих важливих факторів. 
Члени робочої клінічної групи з нюху розробили рекомендацію щодо відновлення нюху, обговорили діагностичну роль оральних стероїдів та висловились за краплі вітаміну А. Потрібні подальші дослідження, які б підтвердили роль інших лікарських засобів [1].

На даний момент переконливого специфічного медикаментозного лікування втраченого смаку і нюху не існує. В ряді спостережень, вивчалася ефективність добавок з цинком, вітаміном Д, Е, В12, сульфатом цинку, теофіліну, альфа-ліпоєвої кислоти [7]. На жаль, вагомих доказів ефективності запропонованих підходів не підтверджено.

Висновки. Аналізуючи отримані дані, можна стверджувати, що результати ряду досліджень підтверджують ефективність нюхової терапії у відновленні порушених смаку та запаху. Збільшення тривалості нюхової терапії та зміна запахів підвищують рівень успіху цієї терапії.

\section{Література:}

1. Addison A. Clinical Olfactory Working Group consensus statement on the treatment of postinfectious olfactory dysfunction / A. Addison, B. Wong, T. Ahmed, A. Macchi at all. // .J. Allergy Clin Immunol. 2021 Jan 13:S00916749(21)00004-X. doi: 10.1016/j.jaci.2020.12.641.

2. Altundag A., Modified olfactory training in patients with postinfectious olfactory loss. Laryngoscope. 2015. Aug;125 (8):1763-6. doi: 10.1002/lary.25245.

3. Coelho D. H. Quality of life and safety impact of COVID-19 associated smell and taste disturbances. // D.H. Coelho, E. R. Reiter, S. G. Budd, Y. Shin at all. // Am J Otolaryngol. 2021 Mar 22;42(4). doi: 10.1016/j.amjoto. 2021.103001 .

4. Damm M. Olfactory training is helpful in postinfectious olfactory loss: a randomized, controlled, multicenter study. // M. Damm, L. K. Pikart, H. Reimann, S. Burkert at all. // Laryngoscope. 2014 Apr;124(4). P. 26 - 31. doi: 10.1002/lary.24340.

5. Joel D. Identifying Treatments for Taste and Smell Disorders: Gaps and Opportunities / Mainland D. Joel, Linda A. Barlow, Steven D. Munger, Sarah E. Millar at all. // Chemical Senses, 2020, Vol 45. - P. 493-502.

6. Mehraeen E. Olfactory and gustatory dysfunctions due to the coronavirus disease (COVID-19): a review of current evidence. / E. Mehraeen, F. Behnezhad, M. A. Salehi, T. Noori, at all. // Eur Arch Otorhinolaryngol. 2021 Feb;278(2). - P. 307-312. doi: 10.1007/s00405-020-06120-6.

7. Richard 1. Doty. Treatments for smell and taste disorders: A critical review / Chapter in Handbook of Clinical Neurology. - Vol. 164 (3rd series). 
8. Samaranayake L.P. Sudden onset, acute loss of taste and smell in coronavirus disease 2019 (COVID-19): a systematic review. / L.P. Samaranayake, K.S. Fakhruddin, C. Panduwawala// Acta Odontol Scand. 2020 Aug;78(6). - P. 467-473. doi: 10.1080/00016357.2020.1787505.

9. Wong D.K.C, A review of smell and taste dysfunction in COVID-19 patients. / D.K.C. Wong, H. S Gendeh, H. K. Thong, S.G. Lum, at all. // Med J Malaysia. 2020 Sep;75(5). - P. 574-581.

10. Zhang Y. Smell disorders in COVID-19 patients: role of olfactory training: A protocol for systematic review and meta-analysis. / Y. Zhang, T. Mei, Y. Chen, L. Wang at all. // Medicine (Baltimore). 2021 Feb 26;100(8):e24862. doi: 10.1097/MD.0000000000024862.

DOI https://doi.org/10.30525/978-9934-26-075-9-43

\title{
ВИЗНАЧЕННЯ СТЕХІОМЕТРИЧНИХ КОЕФІЦІСНТІВ РЕАКЦІЇ СОТАЛОЛУ ТА ДІАЗОЛЮ ЧЕРВОНОГО 2Ж
}

\author{
Малецька О. Р. \\ асистент кафедри аналітичної хімії \\ Запорізький державний медичний університет \\ Васюк С. O. \\ доктор фармачевтичних наук, професор, \\ завідувач кафедри аналітичної хіміі \\ Запорізький державний медичний університет \\ Коржова А. C. \\ кандидат фармацевтичних наук, \\ дочент кафедри аналітичної хімї \\ Запорізький державний медичний університет \\ м. Запоріжжя, Украӥна
}

Соталол (N-[4-[1-Гидрок-2-[(1-метилетил)аміно]етил]феніл]метансульфонамид) - синтетичний лікарський препарат, що належить до групи неселективних бета-блокаторів [1, с. 374].

Метою роботи було встановити склад продукту реакції соталолу та діазолю червоного $2 Ж$, який використовували в якості кольорореагента. 